\title{
PENDIDIKAN MULTIKULTURAL DALAM PERSPEKTIF SAID AGIL HUSIN AL-MUNAWAR
}

\author{
M. Nadlir \\ (Dosen FITK IAIN Sunan Ampel)
}

\begin{abstract}
Abstrak
Tulisan ini memaparkan pemikiran pendidikan multikultural menurut Said Agil Husin Al-Munawar. Dalam perspektif Said Agil Husin AlMunawar, pendidikan multikultural di Indonesia dianggap sebagai sesuatu yang relatif baru di tengah masyarakat Indonesia yang heterogen. Menurut SAH Al-Munawar, agar siswa memiliki pribadi yang aktif dan kepekaan sosial yang tinggi terkait dengan kondisi multikultural, maka pendidikan multikultural di Indonesia dapat mencakup tiga hal jenis transformasi, yakni: 1. Transformasi diri; 2. Transformasi sekolah dan proses belajar-mengajar; 3 . Transformasi masyarakat. Menurut SAH Al-Munawar, dengan belajar dari model-model pendidikan multikultural yang pernah ada yang sedang dikembangkan oleh negara-negara maju, maka dikenal lima model pendidikan multikultural, yaitu: Pertama, pendidikan mengenai perbedaanperbedaan kebudayaan atau multikulturalisme penuh kebaikan. Kedua, pendidikan mengenai perbedaan-perbedaan kebudayaan atau pemahaman kebudayaan. Ketiga, pendidikan bagi pluralisme kebudayaan. Keempat, pendidikan dwi-budaya. Kelima, pendidikan multikultural sebagai pengalaman moral manusia.
\end{abstract}

Kata Kunci: Said Agil Husin Al-Munawar dan Pendidikan Multikultural 


\section{A. Pendahuluan}

Dalam konteks masyarakat yang multikultur dan multireligius, pergesekan antar agama dengan berbagai dimensi kepentingan sosialkemasyarakatan, tatanan ekonomi, struktur kekuasaan dan ideologi sosial-politik yang cenderung hegemonik seringkali menjadi persoalan yang cukup kompleks dan problematis. ${ }^{1}$ Pada perkembangannya, fenomena agama yang menjelma dalam konteks masyarakat yang memiliki tingkat heterogenitas dan pluralitas yang tinggi, amat potensial memunculkan konflik. ${ }^{2}$ Lahirnya konflik ini selain dipicu oleh adanya perbedaan keyakinan dan keragaman pemahaman terhadap doktrinnormatif (kitab suci khususunya), ${ }^{3}$ juga muncul terutama ketika agama telah terkait sedemikian erat dengan kepentingan ekonomi dan politik para pemeluknya yang tidak saja melahirkan konflik internal di dalam suatu kelompok keagamaan. ${ }^{4}$

Dalam situasi konflik, efek yang lebih besar dan sangat mengkhawatirkan adalah munculnya konflik lintas agama dan lintas kultur yang seringkali berkait-kelindan dengan persoalan sosial, politik, ekonomi, ras, gender, dan lain sebagainya. ${ }^{5}$ Oleh karena itu, pluralisme perlu ditegaskan pada pluralisme budaya yang dijabarkan ke dalam sembilan identitas budaya, yaitu: kelas sosial, ras, etnik, gender, perkecualian, agama, bahasa, usia, dan letak geografis. ${ }^{6}$

Demi menjawab persoalan ini, maka di dunia pendidikan dicanangkan sebuah konsep pendidikan guna menjembatani berbagai

\footnotetext{
${ }^{1}$ Kuntowijoyo, Paradigma Islam: Interpretasi untuk Aksi (Bandung: Mizan, 1998), 337.

2 Syafa'atun Elmirzana, "Pluralisme, Konflik dan Dialog (Analisa dan Refleksi)", Esensia, 2. (Januari, 2001), 41.

${ }^{3}$ Alwi Shihab, Islam Inklusif: Menuju Sikap Terbuka dalam Beragama (Bandung: Mizan, 1997), 6. Lihat juga dalam Komarudin Hidayat "Agama-agama Besar Dunia: Masalah Perkembangan dan Interelasi" dalam Komarudin Hidayat dan Ahmad Gaus AF (editor), Passing Over Melintasi Batas Agama (Jakarta: Gramedia, 1999), 209.

${ }_{5}^{4}$ Syafa'atun Elmirzana, "Pluralisme...Op. Cit., 41.

5 A. A. Engineer, "On Religious and Intercultural Dialogue," dalam http./www.global.net.com., Dikutip pada 11 April 2011. Lihat pula Hasan Hanafi, Islam in The Modern World: Tradition, Revolution and Culture Vol.II (Kairo: Dar Keba Bookshop, 2000), 557-559.

${ }^{6}$ Donna M. Gollich dan Philip C. Chinn, Multikultural Education in a Pluralistic Society (New Jersey: Pearson Education Inc., 2002), 19.
}

Jurnal Pendidikan Agama Islam Volume 01 Nomor 01 Mei 2013 Hal $62-77$ 
persoalan pluralisme dan kompleksitas kultural yang beragam. Konsep ini disebut dengan multicultural education (pendidikan multikultural), yaitu suatu proses pendidikan yang memungkinkan individu untuk mengembangkan diri dengan cara merasa, menilai, dan berperilaku dalam sistem budaya yang berbeda dengan sistem budaya mereka. ${ }^{7}$

Pendidikan multikultural dipilih sebagai sebuah solusi untuk memaksimalkan pemahaman nilai-nilai pluralisme dalam sistem pendidikan, karena strategi pendidikan ini mengadopsi nilai-nilai yang terdapat dalam budaya yang berbeda-beda dan berusaha menegakkan pluralisme dengan cara menanamkannya ke dalam diri siswa, guru, dan komunitas mereka. Di samping itu, pendidikan multikultural menolak segala bentuk diskriminasi di sekolah dan masyarakat dengan cara mempromosikan prinsip-prinsip demokrasi dan keadilan sosial. ${ }^{8}$

Sebenarnya, pendidikan multikultural dengan mengacu pada entitas budaya, telah ada pada diri masing-masing individu, institusi sekolah, dan dunia pendidikan pada umumnya. Persoalannya, sejauhmana kesadaran nilai-nilai multikultural pada diri masing-masing individu itu teraktualisasi dalam kehidupannya. Untuk mengktualisasikan nilai-nilai multikultural menjadi praktik dalam kehidupan masyarakat, maka diperlukan suatu upaya pengkondisian yang mengarah pada situasi tersebut.

Di tengah kondisi keharmonisan hidup antar umat beragama dan berbudaya yang semakin terancam, maka internalisasi nilai-nilai multikultural ke dalam diri masyarakat -salah satunya melalui dunia pendidikan- semakin dibutuhkan. Oleh karenanya, diseminasi konsep pendidikan multikultural dari para ilmuwan perlu dilakukan. Dalam konteks ini, kajian penelitian akan fokus pada pendidikan multikultural dalam pandangan Said Agil Husin Al-Munawar. Pemikiran-pemikiran pendidikan multikultural Said AH Al-Munawar akan dieksplorasi dalam kajian penelitian ini.

${ }^{7}$ Hilda Hernandez, Multikultural Education; A Teachers Guide to Linking Context, Process, and Content (New Jersey: Merrill Prentice Hall Inc., 2001), 5.

8 Paul Gorski at. al., "National Association Multikultural Education," dalam http./www.mhe.com., Dikutip pada 11 April 2011. 
M. Nadlir

\section{B. Mengenal Said Agil Husin Al-Munawar}

Prof. Dr. H. Said Agil Husin Al Munawar, M.A. lahir di Palembang, 26 Januari 1954. Dia meraih gelar sarjana S-1 pada Fakultas Syari'ah IAIN Raden Fatah Palembang (1974), LML (1983), dan Ph.D (1987) dari Fakultas Syari'ah University Ummul Qura Makkah, Saudi Arabia. Dia merupakan salah seorang Hafizh (Penghafal a-Quran alKarim) terbaik di Indonesia.

Said Agil Husin Al-Munawar merupakan salah seorang Guru Besar dalam bidang Fiqh dan Ushul Fiqh pada Fakultas Ushuluddin UIN Syarif Hidayatullah Jakarta. Semenjak tahun 1999 sebagai Direktur Program Pascasarjana UIN Syarif Hidayatullah Jakarta. Pada pemerintahan Kabinet Presiden Megawati Soekarno Putri dipercaya sebagai Menteri Agama RI. ${ }^{9}$

Sejumlah karya yang telah dipublikasikan di antaranya; I'jazal al-Qur'an dan Metodologi Tafsir, Ushul Fiqh: Sejarah dan Suatu Pengantar, Ilmu Takhrij Hadis: Sejarah dan Suatu Pengantar, Perkembangan Hukum Islam Madzab Syafi'i: Studi Qaul Qadim dan Qaul Jadid, Dimensi-dimensi Kehidupan dalam Perspektif Islam, Naqlu al-Dam wa Astaruhu fi al-Syari'ah al-Islamiyah, Al-Khamru wa Adlararuhu fi al-Mujtma'i al-Insani Al-Nadbu wa Al-Karahah (Tesis S2 Ummul Qura, 1983), dan Tahqiq kitab Hawi al-Kabir karya al-Mawardi (Pemikiran Hukum Islam Al-Mawardi dalam Kitab al-Hawi al-Kabir Disertasi Ph.D. 1987), Al Quran Membangun Tradisi Kesalehan Hakiki, Fikih Hubungan Antar Agama, dan Fikih Haji: Menuntut Jama'ah Menuju Haji Mabrur.

\section{Gagasan Awal Pendidikan Multikultural di Indonesia}

Konsep pendidikan multikultural di negara-negara yang menganut konsep demokratis seperti Amerika Serikat dan Kanada, bukan hal baru lagi. Mereka telah melaksanakannya, khususnya dalam upaya melenyapkan diskriminasi rasial antara orang kulit putih dan kulit hitam, yang bertujuan memajukan dan memelihara integritas nasional. Berbagai

9 Said Agil Husin Al Munawar, Aktualisasi Nilai-Nilai Qur'ani dalam Sistem Pendidikan Islam (Jakarta: Ciputat Press, 2003), 
model pendidikan multikultural diterapkan di sekolah-sekolah Amerika Serikat dan hasilnya pun dievaluasi.

Di Indonesia, menurut Said Agil Husin Al-Munawar, pendidikan multikultural relatif baru dikenal sebagai suatu pendekatan yang dianggap lebih sesuai bagi masyarakat Indonesia yang heterogen, terlebih pada masa otonomi dan desentralisasi yang merupakan kebijakan yang baru dilaksanakan. Pendidikan multikultural yang dikembangkan di Indonesia sejalan dengan pengembangan demokrasi yang dijalankan sebagai counter terhadap kebijakan desentralisasi dan otonomi daerah. Apabila hal itu dilaksanakan dengan tidak berhati-hati justru akan menjerumuskan generasi bangsa kedalam perpecahan nasional. ${ }^{10}$

Secara esensial, doktrin Islam sebenarnya tidak membedabedakan etnik, ras dan lain sebagainya dalam pendidikan. Semua manusia adalah sama, yang membedakannya adalah ketakwaan mereka kepada Allah SWT. Dalam Islam pendidikan multikultural barangkali dapat dilihat dari tingginya penghargaan Islam terhadap ilmu pengetahuan. Tidak ada perbedaan di antara manusia dalam bidang ilmu.

Secara sederhana pendidikan multikultural dapat didefinisikan sebagai "pendidikan untuk/tentang keragaman kebudayaan dalam merespon perubahan dengan demografis dan kultural lingkungan masyarakat tertentu atau bahkan dunia secara keseluruhan". Dengan demikian pendidikan multicultural selalu terkait dengan kebudayaan dan kultur lingkungan. Ini berarti pembahasan tentang pendidikan multikultural tak dapat dipisahkan dari budaya dan lingkungan sekitar masyarakat.

Bagi Said Agil Husin (SAH) Al-Munawar, definisi di atas agar lebih bermanfaat dan memberikan pengalaman empiris bagi orang yang membacanya, maka diperlukan sebuah definisi ulang terhadap "budaya" dan "kebudayaan". Upaya memberikan perumusan ini tidaklah mudah, sebab suasana perubahan demi perubahan yang begitu cepat dan dramatis terjadi dalam kebudayaan itu sendiri, khususnya karena proses globalisasi yang semakin meningkat. ${ }^{11}$

${ }^{10}$ Al Munawar, Aktualisasi ..., Ibid., 211.

${ }^{11}$ Al Munawar, Aktualisasi ..., Ibid. 
Pendidikan multikultural adalah pendidikan yang mempelajari tentang perbedaan budaya serta memberikan kesempatan pendidikan yang sama untuk semua murid, memperkenalkan budaya-budaya lain, dan meningkatkan toleransi dan apresiasi pada perbedaan etnik. Pendidikan multikultural diharapkan akan membantu mengurangi sikap rasialisme dan tensi konflik.

Pendidikan multikultural merupakan upaya kolektif suatu masyarakat majemuk untuk mengelola berbagai prasangka sosial yang ada dengan cara-cara yang baik. Tujuannya, menciptakan hubungan lebih serasi dan kreatif di antara berbagai golongan penduduk dalam masyarakat. Pendidikan multikultural menyarankan agar para siswa di sekolah dapat menghargai temannya yang berasal dari suku lain, dan mengetahui bahwa di Indonesia terdapat bermacam-macam suku bangsa, sehingga tidak terjadi lagi konflik antar agama atau suku. ${ }^{12}$ Nilai-nilai multikultural yang harus dikembangkan -antara lain- toleransi, empati, solidaritas, pengungkapan diri, dan keadilan.

Tujuan pendidikan multikultural adalah menciptakan lingkungan sekolah yang membantu perkembangan budaya plural (beragam). Di dalam kelas multikultural, semua murid dari berbagai budaya dan bahasa memiliki kesempatan pendidikan yang sama. Pembelajaran merefleksikan budaya, pengalaman, perspektif tentang linguistik dan budaya suatu kelompok, serta penghormatan terhadap perbedaan dan kesamaan budaya murid.

Pendidikan multikultural berawal dari berkembangnya gagasan dan kesadaran tentang "interkulturalisme" seusai Perang Dunia II. Kemunculan gagasan dan kesadaran "interkulturalisme" ini selain terkait dengan perkembangan politik internasional menyangkut HAM, kemerdekaan dari kolonialisme, dan diskriminasi rasial dan lain-lain, juga karena meningkatnya pluralitas di negara-negara Barat sendiri sebagai

\footnotetext{
${ }^{12}$ Murniati Agustian, Maria G. Da Cunha, Syarief Darmoyo, dan M. Tri Warmiyati, "Pengembangan Model Pendidikan Multikulturalisme Untuk Anak Usia Sekolah: Menggunakan Seri Pustaka Anak Nusantara", Laporan Penelitian, 2006, dalam http://www.atmajaya.ac.id/ content.asp?f=13\&id=3096, akses 03 September 2011.
} 
akibat dari peningkatan migrasi dari negara-negara yang baru merdeka ke Amerika dan Eropa. ${ }^{13}$

Di dalam program pendidikan multikultural, fokus tidak lagi diarahkan semata-mata kepada kelompok rasial, agama dan kultural domain atau mainstream. Fokus seperti ini pernah menjadi tekanan pada pendidikan interkultural yang menekankan peningkatan pemahaman dan toleransi individu-individu yang berasal dari kelompok minoritas terhadap budaya mainstrem yang dominan, yang pada akhirnya menyebabkan orang-orang dari kelompok minoritas terintegrasi kedalam masyarakat mainsterm. Pendidikan multikultural sebenarnya merupakan sikap "peduli" dan mau mengerti (difference), atau "politics of recognition" (politik pengakuan) terhadap orang-orang dari kelompok minoritas.

Dalam konteks itu, pendidikan multikultural melihat masyarakat secara lebih luas. Berdasarkan pandangan dasar bahwa sikap "indeference" dan "non-recognition" tidak hanya berakar dari ketimpangan struktur rasial, tetapi paradigma pendidikan multikultural mencakup subjek-subjek mengenai ketidakadilan, kemiskinan, penindasan, dan keterbelakangan kelompok-kelompok minoritas dalam berbagai bidang; sosial, budaya, ekonomi, pendidikan, dan lain sebagainya. Paradigma seperti ini akan mendorong tumbuhnya kajiankajian tentang "ethnic studies" untuk kemudian menemukan tempatnya dalam kurikulum pendidikan sejak dari tingkat dasar sampai ke perguruan tinggi. Tujuan inti dari pembahasan tentang semua subjek ini adalah untuk mencapai pemberdayaan (empowermant) bagi kelompok-kelompok minoritas dan disadventaged. ${ }^{14}$

Istilah "pendidikan multikultural" dapat digunakan baik pada tingkat deskriptif dan normatif, yang menggambarkan isu-isu dan masalah-masalah pendidikan berkaitan dengan masyarakat multikultural. Lebih jauh ia juga mencakup pengertian tentang pertimbangan terhadap kebijakan-kebijakan dan sttrategi-strategi pendidikan dalam masyarakat multikultural. Dalam konteks deskriptif ini, maka kurikulum pendidikan

13 H.A.R. Tilaar, Multikulturalisme Tantangan-Tantangan Global Masa Depan dalam Transformasi Pendidikan Nasional (Jakarta: Grasindo, 2004), 495-497.

${ }^{14}$ Tilaar, Multikulturalisme, Ibid., 498. 
multikultural mencakup subjek-subjek seperti: toleransi; tema-tema tentang perbedaan ethno-kultural, dan agama; bahaya diskriminasi; penyelesaian konflik dan mediasi; HAM; demokratis dan pluralitas; kemanusiaan universal dan subjek-subjek lain yang relevan.

\section{Corak Penerapan Pendidikan Multikultural}

Penerapan pendidikan multikultural semestinya memfasilitasi proses belajar mengajar yang mengubah perspektif monokultural yang esensial, penuh prasangka dan bersifat diskriminatif ke perspektif multikulturalis yang menghargai keragaman dan perbedaan, toleran dan bersifat terbuka. Perubahan paradigma semacam ini menuntut transformasi yang tidak terbatas pada dimensi kognitif belaka.

Bagi SAH Al-Munawar, model pemikiran yang ada di Indonesia maupun di negara-negara lain menunjukkan keragaman tujuan yang menerapkan strategi dan sarana yang dipakai untuk mencapainya. Sejumlah kritikus melihat bahwa revisi kurikulum sekolah yang dilakukan dalam program pendidikan multikultural di Inggris dan di beberapa tempat di Australia dan Kanada, terbatas pada keragaman budaya yang ada, jadi terbatas pada dimensi kognitif. ${ }^{15}$

Penambahan informasi tentang keragaman budaya merupakan model pendidikan multikultural yang mencakup revisi isi atau materi pembelajaran, termasuk revisi buku-buku teks. Terlepas dari kritik atas penerapannya di beberapa tempat, revisi pembelajaran seperti di Amerika Serikat merupakan strategi yang dianggap paling penting dalam reformasi pendidikan dan kurikulum. Penulisan kembali sejarah Amerika dari perspektif yang lebih beragam merupakan suatu agenda pendidikan yang diperjuangkan intelektual, aktivis dan praktisi pendidikan.

Di Jepang aktivis kemanusiaan melakukan advokasi serius untuk merevisi buku sejarah, terutama yang menyangkut peran Jepang pada Perang Dunia II di Asia. Walaupun belum diterima, usaha ini sudah mulai membuka mata sebagian masyarakat akan pentingnya perspektif baru tentang perang, agar tragedi kemanusiaan tidak terulang kembali. Sedangkan di Indonesia masih diperlukan usaha yang panjang dalam merevisi buku-buku teks agar mengakomodasi kontribusi dan partisipasi

${ }^{15}$ Al Munawar, Aktualisasi ..., Op.Cit., 213. 
yang lebih inklusif warga dari berbagai latar belakang dalam pembentukan Indonesia. Indonesia juga memerlukan pula materi pembelajaran yang bisa mengatasi "dendam sejarah" di berbagai wilayah.

Di samping itu, ada model penerapan pendidikan multikultural yang tidak sekedar merevisi materi pembelajaran tetapi melakukan reformasi dalam sistem pembelajaran itu sendiri. Affirmative action dalam seleksi siswa sampai rekrutmen pengajar di Amerika adalah salah satu strategi untuk membuat perbaikan ketimpangan struktural terhadap kelompok monoritas. Contoh yang lain adalah model "sekolah pembauran" Iskandar Muda di Medan yang memfasilitasi interaksi siswa dari berbagai latar belakang budaya, dan menyusun program anak asuh lintas kelompok. Pada tahun 1980-an di Amerika Serikat bersamaan dengan masuknya wacana multikulturalisme, dilakukan berbagai loka karya di sekolah-sekolah maupun di masyarakat luas untuk meningkatkan kepekaan sosial, toleransi dan mengurangi prasangka antar kelompok. Model-model ini seperti diintegrasikan juga dalam proses belajarmengajar di sekolah. ${ }^{16}$

Model tersebut di atas menunjukkan bagaimana sekolah dianggap sebagai media yang penting dan strategis untuk perubahan perspektif siswa dengan harapan akan perubahan masyarakat di masa yang akan datang. Dengan demikian, model penerapan pendidikan multikultural di atas sebagai "filsafat, metodologi untuk melakukan reformasi pendidikan", atau sekedar "satu set substansi pelajaran dengan program pembelajarannya".

Secara lebih menyeluruh pendidikan multikultural adalah suatu pendekatan progresif untuk melakukan transformasi pendidikan yang secara menyeluruh membongkar kekurangan, kegagalan dan praktikpraktik diskriminatif dalam proses pendidikan. Pendidikan multikultural didasarkan pada gagasan keadilan sosial dan persamaan hak dalam pendidikan. Pendidikan multikultural merupakan suatu komitmen untuk memfasilitasi pengalaman belajar yang memungkinkan setiap siswa mencapai potensi maksimal sebagai pelajar dan sebagai pribadi yang aktif dan memiliki kepekaan sosial tinggi di tingkat lokal, nasional dan global.

${ }^{16}$ Al Munawar, Aktualisasi ..., Ibid., 214-215 
Menurut SAH Al-Munawar, agar siswa memiliki pribadi yang aktif dan kepekaan social yang tinggi terkait dengan kondisi multicultural, maka pendidikan multikultural di Indonesia perlu memakai kedua model diatas. Dengan meminjam analisis Gorski, Al-Munawar menyatakan bahwa pendidikan multikultural dapat mencakup tiga hal jenis transformasi, yakni:

1. Transformasi diri;

2. Transformasi sekolah dan proses belajar-mengajar;

3. Transformasi masyarakat. ${ }^{17}$

Pendidikan multikultural amat penting diterapkan di semua sekolah. Melalui model pembelajaran multikultural siswa diperkenalkan dan diajak megembangkan nilai-nilai dan sikap toleransi, solidaritas, empati, musyawarah, dan egaliter. Dengan ini, siswa juga memahami kearifan lokal yang merupakan bagian dari budaya bangsa ini, dan ini dapat mencegah terjadinya konflik. ${ }^{18}$

Program pengembangan pendidikan multikultural tidak mutlak harus menjadi mata pelajaran yang berdiri sendiri, namun dapat terintegrasi kedalam mata pelajaran, sehingga dalam implementasinya perlu dilakukan oleh guru-guru yang kreatif dan inovatif. Guru-guru dituntut kreatif dan inovatif sehingga mampu mengolah dan menciptakan desain pembelajaran yang sesuai dengan nilai-nilai multikultural, termasuk memberikan dan membangkitkan motivasi siswa dalam memahami dan bersikap sesuai dengan wawasan multikultural.

Menyusun pendidikan multikultural dalam tatanan masyarakat yang masih penuh permasalahan antar kelompok mengandung tantangan yang tidak ringan. Pendidikan multikultural tidak berarti sebatas "merayakan keragaman" belaka. Apalagi jika tatanan masyarakat yang ada masih penuh diskriminasi dan bersifat rasis. Dapat pula dipertanyakan apakah mungkin meminta siswa yang dalam kehidaupan sehari-hari mengalami diskriminasi atau penindasan karena warna kulitnya atau perbedaannya dari budaya dominan, untuk merayakan perbedaan tersebut? Dalam kondisi demikian, pendidikan multikultural

\footnotetext{
${ }^{17}$ Al Munawar, Aktualisasi..., Ibid., 215.

Jurnal Pendidikan Agama Islam Volume 01 Nomor 01 Mei 2013

Hal $70-77$
}

18 "Pendidikan Multikultural Tanamkan Sikap Menghargai Keberagaman", dalam http://www. kaskus.us/ showthread.php?t=427469, akses 03-09-2011. 
lebih tepat diarahkan sebagai advokasi untuk menciptakan masyarakat yang toleran dan bebas dari diskriminasi.

Di Indonesia penerapan pendidikan multikultural mendapat tantangan yang tidak mudah untuk dipikirkan. Mengingat pendidikan formal di Indonesia masih sarat dengan persoalan-persoalan mendasar berkaitan dengan sumber daya sampai dengan substansi dan sistem belajar-mengajar. Jika modul-modul pendidikan multikultural sudah disusun, siapkah pengajar untuk menerapkannya dan bagaimana mengintegrasikannya dalam kurikulum yang sudah terlalu sarat dengan berbagai macam indoktrinisasi? Persoalan-persoalan ini merupakan tantangan bagi penerapan pendidikan multikultural di Indonesia.

Sementara itu arena politik dan kenegaraan tempat pendidikan formal di negeri ini diwarnai berbagai intrik, dan pertarungan kekuasaan yang membuat suasana kurang kondusif bagi penerapan pendidikan multikultural. Rancangan Undang-undang Sistem Pendidikan Nasional sempat menimbulkan kontroversi di kalangan praktisi pendidikan bahkan juga kelompok masyarakat yang konsen dalam bidang pendidikan tahun 2003, terutama butir yang mengatur pelaksanaan pengajaran agama di sekolah-sekolah formal.

Kewajiban mengajarkan agama sesuai yang dianut siswa satu sisi bisa dilihat sebagai hak yang sesuai dengan latar belakang budaya warga. Di lain pihak jika kewajiban itu dikenakan pada sekolah-sekolah yang secara khusus memiliki identitas keagamaan tertentu, maka kebijakan itu berimplikasi pada hak kelompok budaya untuk mengaktualisasikan misi kelompoknya. Pada saat yang sama rancangan tersebut dapat berdampak mengintervensikan suatu proses pembelajaran lintas agama yang secara tak dipaksakan telah terjadi melalui institusi sekolah-sekolah berbasis agama tersebut.

\section{E. Pendekatan dalam Pendidikan Multikultural}

Menurut SAH Al-Munawar, dengan belajar dari model-model pendidikan multikultural yang pernah ada yang sedang dikembangkan oleh negara-negara maju, maka dikenal lima model pendidikan multikultural, yaitu: Pertama, pendidikan mengenai perbedaan-perbedaan kebudayaan atau multikulturalisme penuh kebaikan. Kedua, pendidikan 
mengenai perbedaan-perbedaan kebudayaan atau pemahaman kebudayaan. Ketiga, pendidikan bagi pluralisme kebudayaan. Keempat, pendidikan dwi-budaya. Kelima, pendidikan multikultural sebagai pengalaman moral manusia. ${ }^{19}$

Pendekatan pertama hingga keempat berasal dari tradisi ilmu kependidikan mengenai dwi-budaya dan pendidikan multikultural. Sementara itu pendekatan yang kelima bermula dari konsep-konsep kunci mengenai pendidikan dan kebudayaan, yakni konsep-konsep yang bersumber dari antropologi. Konseptualisasi pendidikan multikultural dikembangkan dari konsep-konsep itu sendiri, bukan dari programprogam sekolah yang sedang berjalan atau tengah diwujudkan, dimana bobot dan mutu yang bersifat multikultural ditambahkan programprogram tersebut. Dalam pendekatan ini, menurut pandangan antropolog bahwa pendidikan adalah dasar suatu proses kebudayaan.

Meskipun pendidikan itu dapat diperdebatkan lebih lanjut relevansi dan keberlakuannya, barangkali perlu dikemukakan secara jelas pendapat Spindler yang memandang pendidikan itu sebagai transmisi kebudayaan. Antropologi memandang pendidikan sebagai bagian dari proses sosialisasi yang dialami manusia, dimana orang-orang muda mempersiapkan diri untuk menyesuaikan diri dengan baik kedalam lingkungan internal komunitas dimana mereka hidup dan menjadi dewasa, dan menjadi bagian dari lingkungan eksternal dimana hidup komunitas manusia yang lebih luas dan total.

Berkaitan dengan hal di atas, Goodenough mengomentari tentang kebudayaan. Kebudayaan itu sebagai standar bagi orang untuk mempersepsi, mengevaluasi, meyakini dan melakukan. Kebudayaan dapat didefinisikan sebagai standar yang harus diikuti seseorang dan standar-standar tersebut berbeda pada sejumlah orang. Dengan demikian tentu mereka memiliki kebudayaan yang berbeda. Seseorang tidak hanya harus mewujudkan sistem standar yang berbeda bagi sejumlah orang yang berbeda-beda melainkan memiliki kompetensi dalam mengakomodir berbagai kebudayaan yang dihadapi.

Pandangan Spindler dan Goodenough di atas relevan untuk dikemukakan di sini mengingat dua alasan. Pertama, definisi Spindler

${ }^{19}$ Al Munawar, Aktualisasi..., Op.Cit., 217. 
mengenai pendidikan sebagai transmisi kebudayaan, meski masih mengandung warna kuat paradigma struktural-fungsionalisme klasik yang keberlakuannya mungkin terbatas pada black box masyarakat dan kebudayaan sederhana secara tipologis, tetap relevan dan penting untuk mendiskusikan proses belajar-mengajar dalam kelas atau sekolah sebagai miniatur masyarakat. Kedua, pendapat Goodenough mengandung isyarat yang kuat bagi pentingnya bahasa dalam mengembangkan kompetensi sistem standar atau kebudayaan tersebut. Hal ini menunjukkan bahwa ada dua pertautan yang kuat antara pandangan Spindler dan Goodenough dalam mendiskusikan lebih jauh konsep pendidikan multikultural tersebut. $^{20}$

Pengenalan dan sosialisasi program penerapan pendidikan multikultural dapat dilakukan dengan menggunakan film semi dokumenter. Mengingat pembelajaran ini menawarkan metodologi dan pendekatan yang berbeda dari model-model pembelajaran konvensional yang selama ini dicekokkan ke siswa. Metodologi dan strategi pembelajaran multikultural dengan menggunakan sarana audio visual cukup menarik minat belajar anak serta sangat menyenangkan bagi siswa dan guru. Karena, siswa secara sekaligus dapat mendengar, melihat, dan melakukan praktik selama proses pembelajaran berlangsung. ${ }^{21}$

Menurut SAH Al-Munawar, ada beberapa pendekatan dalam proses pendidikan multikultural, yaitu:

Pertama, tidak lagi terbatas pada menyamakan pandangan pendidikan (education) dengan persekolahan (schooling) atau pendidikan multikultural dengan program-program sekolah formal. Pandangan yang lebih luas mengenai pendidikan sebagai transmisi kebudayaan membebaskan pendidikan dari asumsi mereka bahwa tanggung jawab primer mengembangkan kompetensi kebudayaan di kalangan anak didik semata-mata berada di tangan mereka dan justru lebih luas dari pada itu, semakin banyak pihak yang bertanggungjawab karena program-program di sekolah seharusnya terkait dengan pembelajaran infomal dan luar sekolah.

\footnotetext{
${ }^{20}$ Al Munawar, Aktualisasi..., Ibid., 218-219.

21 "Pendidikan Multikultural Tanamkan Sikap Menghargai Keberagaman", dalam http://www. kaskus.us/ showthread.php?t=427469, akses 03-09-2011.
} 
Kedua, seseorang tidak lagi terbatas pada pandangan yang menyatakan kebudayaan dengan kelompok etnik adalah sama. Berarti, seseorang tidak perlu mengasosiasikan kebudayaan semata-mata dengan kelompok-kelompok etnik sebagaimana selama ini orang terbiasa melakukannya. Secara tradisional para pendidik mengasosiasikan kebudayaan hanya dengan kelompok-kelompok sosial yang relatif self sufficient, ketimbang dengan sejumlah orang yang secara terus-menerus dan berulang-ulang terlibat satu sama lain dalam satu atau lebih kegiatan.oleh karena individu-individu memiliki berbagai tingkat kompetensi dalam berbagai dialek atau bahasa dan berbagai pemahaman mengenai berbagai situasi dimana setiap pemahaman tersebut sesuai, maka individu-individu memiliki berbagai tingkat kompetensi dalam sejumlah kebudayaan.

Walaupun kelompok etnik mungkin memiliki standar tertentu, para anggotanya juga dapat dipilah-pilah kedalam sub-sub yang terlibat dalam kegiatan-kegiatan bersama yang khusus pula, misalnya, kegiatan pekerjaan, keagamaan, atau reaksi. Sebagian dari kegiatan ini barangkali lintas batas etnik, sehingga dapat dilihat bahwa anggota-anggota kelompok etnik tertentu akan merepresentasikan suatu rentang kebudayaan yang lebih luas.

Dalam konteks pendidikan multikultural, jika pendekatan ini dipahami dan diadopsi oleh para penyusun program-program pendidikan multikultural, akan melenyapkan kecenderungan memandang anak didik secara stereotipe menurut identitas etnik mereka dan akan meningkatkan eksplorasi pemahaman yang lebih besar mengenai kesamaan dan perbedaan di kalangan anak didik dari berbagai kelompok etnik.

Ketiga, pengembangan kompetensi dalam suatu "kebudayaan baru" biasanya membutuhkan interaksi inisiatif dengan orang-orang yang sudah memiliki kompetensi, bahkan dapat dilihat lebih jelas bahwa upaya-upaya untuk mendukung sekolah-sekolah yang terpisah secara etnik adalah antitesis terhadap tujuan pendidikan mutikultural. Mempertahankan dan memperluas solidaritas kelompok adalah menghambat sosialisasi kedalam multikultural tidak dapat disamakan secara logis.

Keempat, pendidikan multikultural meningkatkan kompetensi dalam beberapa kebudayaan. Kebudayaan yang akan diadopsi ditentukan 
oleh situasi. Pendidikan (baik di dalam maupun di luar sekolah) memungkinkan untuk meningkatkan kesadaran tentang kompetensi dalam beberapa kebudayaan. Kesadaran seperti ini kemudian akan menjauhkan seseorang dari konsep dwi budaya atau dikotomi antara pribumi dan non-pribumi. Dikotomi semacam ini bersifat membatasi kebebasan individu untuk sepenuhnya bersifat diversitas kebudayaan. Pendekatan ini meningkatkan kesadaran akan multikulturalisme sebagai pengalaman normal manusia. Kesadaran ini mengandung potensi pendidikan multikultural untuk menghindari dikotomi dan mengembangkan apresiasi yang lebih baik melalui kompetensi kebudayaan yang ada pada diri anak didik. ${ }^{22}$

Setidaknya ada dua hal yang perlu dilakukan dalam penerapan pendidikan multikultural di sekolah. Pertama, melakukan dialog dengan menempatkan setiap peradaban dan kebudayaan yang ada pada posisi sejajar. Kedua, mengembangkan toleransi untuk memberikan kesempatan kepada masing-masing kebudayaan untuk saling memahami. Toleransi diperlukan tidak hanya pada tataran konseptual, melainkan juga teknis operasional. $^{23}$

\section{F. Kesimpulan}

Pendidikan multikultural adalah pendidikan yang mengajarkan tentang perbedaan dan keragaman budaya serta memberikan kesempatan pendidikan yang sama untuk semua murid, memperkenalkan budayabudaya lain, dan meningkatkan toleransi dan apresiasi pada perbedaan etnik. Tujuannya, menciptakan hubungan lebih serasi dan kreatif di antara berbagai golongan penduduk dalam masyarakat.

Dalam perspektif Said Agil Husin Al-Munawar, pendidikan multikultural di Indonesia dianggap sebagai sesuatu yang relatif baru di tengah masyarakat Indonesia yang heterogen, terlebih pada masa otonomi dan desentralisasi yang merupakan kebijakan yang baru dilaksanakan. Pendidikan multikultural yang dikembangkan di Indonesia sejalan dengan pengembangan demokrasi yang dijalankan sebagai counter

\footnotetext{
${ }^{22}$ Al Munawar, Aktualisasi..., Op.Cit., 219-221.

23 "Pendidikan Multikultural", dalam http://kompas.com/kompas-cetak/0611/18/ humaniora/ 3102848.htm, 03-09-2011.
} 
terhadap kebijakan desentralisasi dan otonomi daerah. Apabila hal itu dilaksanakan dengan tidak berhati-hati justru akan menjerumuskan generasi bangsa kedalam perpecahan nasional.

Menurut SAH Al-Munawar, agar siswa memiliki pribadi yang aktif dan kepekaan sosial yang tinggi terkait dengan kondisi multikultural, maka pendidikan multikultural di Indonesia dapat mencakup tiga hal jenis transformasi, yakni: 1. Transformasi diri; 2. Transformasi sekolah dan proses belajar-mengajar; 3. Transformasi masyarakat. Menurut SAH Al-Munawar, dengan belajar dari modelmodel pendidikan multikultural yang pernah ada yang sedang dikembangkan oleh negara-negara maju, maka dikenal lima model pendidikan multikultural, yaitu: Pertama, pendidikan mengenai perbedaan-perbedaan kebudayaan atau multikulturalisme penuh kebaikan. Kedua, pendidikan mengenai perbedaan-perbedaan kebudayaan atau pemahaman kebudayaan. Ketiga, pendidikan bagi pluralisme kebudayaan. Keempat, pendidikan dwi-budaya. Kelima, pendidikan multikultural sebagai pengalaman moral manusia.

\section{DAFTAR PUSTAKA}

Alwi Shihab, Islam Inklusif: Menuju Sikap Terbuka dalam Beragama (Bandung: Mizan, 1997).

A. A. Engineer, "On Religious and Intercultural Dialogue," dalam http./www.global.net.com., Dikutip pada 11 April 2011.

Donna M. Gollich dan Philip C. Chinn, Multikultural Education in a Pluralistic Society (New Jersey: Pearson Education Inc., 2002).

Hilda Hernandez, Multikultural Education; A Teachers Guide to Linking Context, Process, and Content (New Jersey: Merrill Prentice Hall Inc., 2001).

H.A.R. Tilaar, Multikulturalisme Tantangan-Tantangan Global Masa Depan dalam Transformasi Pendidikan Nasional (Jakarta: Grasindo, 2004).

Hasan Hanafi, Islam in The Modern World: Tradition, Revolution and Culture Vol.II (Kairo: Dar Keba Bookshop, 2000). 
Kuntowijoyo, Paradigma Islam: Interpretasi untuk Aksi (Bandung: Mizan, 1998).

Komarudin Hidayat "Agama-agama Besar Dunia: Masalah Perkembangan dan Interelasi" dalam Komarudin Hidayat dan Ahmad Gaus AF (editor), Passing Over Melintasi Batas Agama (Jakarta: Gramedia, 1999).

Murniati Agustian, Maria G. Da Cunha, Syarief Darmoyo, dan M. Tri Warmiyati, "Pengembangan Model Pendidikan Multikulturalisme Untuk Anak Usia Sekolah: Menggunakan Seri Pustaka Anak Nusantara", Laporan Penelitian, 2006, dalam http://www.atmajaya.ac.id/ content.asp? $\mathrm{f}=13 \& \mathrm{id}=3096$, akses 03 September 2011.

Paul Gorski at. al., "National Association Multikultural Education," dalam http./www.mhe.com., Dikutip pada 11 April 2011.

"Pendidikan Multikultural Tanamkan Sikap Menghargai Keberagaman", dalam http://www. kaskus.us/ showthread.php?t=427469, akses 0309-2011.

"Pendidikan Multikultural", dalam http://kompas.com/kompascetak/0611/18/humaniora/ 3102848.htm, 03-09-2011.

Said Agil Husin Al Munawar, Aktualisasi Nilai-Nilai Qur'ani dalam Sistem Pendidikan Islam (Jakarta: Ciputat Press, 2003),

Syafa'atun Elmirzana, "Pluralisme, Konflik dan Dialog (Analisa dan Refleksi)", Esensia, 2. (Januari, 2001). 